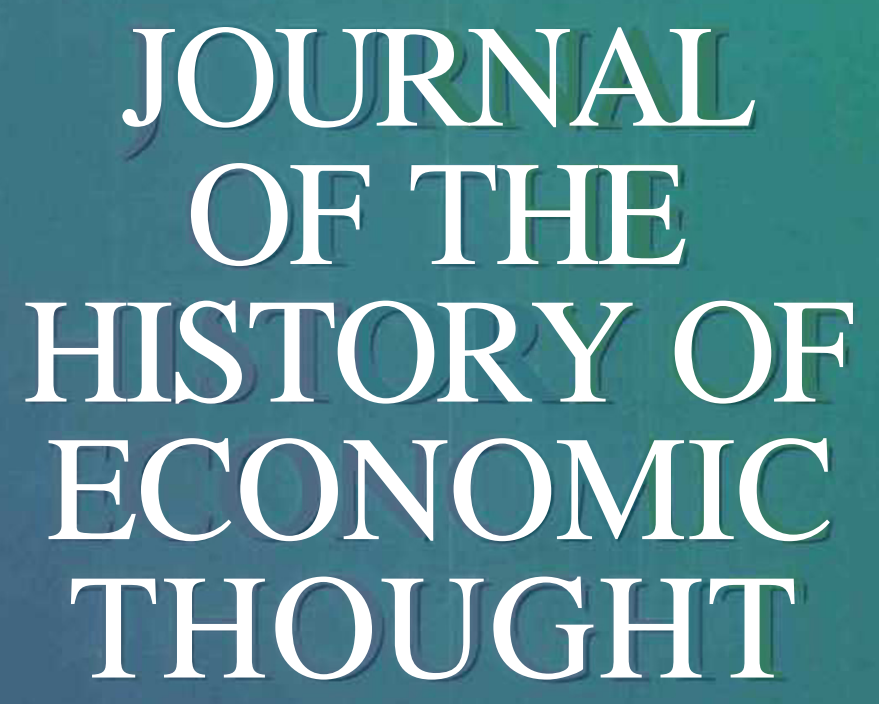

VOLUME 20 NUMBER 3 SEPTEMBER 1998

PUBLISHED FOR THE HISTORY

OF ECONOMICS SOCIETY

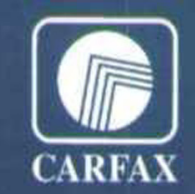

ISSN $1042-7716$ 


\section{JOURNAL OF THE HISTORY OF ECONOMIC THOUGHT}

Journal of the History of Economic Thought (JHET) is the journal of the History of Economics Society. It has been in existence for a number of years, originally as the History of Economics Society Bulletin, and for the last nine years under its present name. The work of many distinguished authors residing in many different countries has been published in its pages, and because of this and the international editorial board, it is recognized as being a first class international scholarly publication. All articles are fully peer reviewed. The journal also features a regular Book Review section which includes reviews by leading specialists.

Editor: Donald A. Walker. Book Review Editor: Paul B. Trescott, Southern Illinois University. Board of Editors: Richard Arena, University of Nice; Roger E. Backhouse, University of Birmingham; Hans Brems, University of Illinois, Urbana Champaign; Robert W. Clower, University of South Carolina; David C. Colander, Middlebury College; Gilles Dostaler, University of Quebec at Montreal; James P. Henderson, Valparaiso University; Samuel Hollander, University of Toronto; Donald E. Moggridge, University of Toronto; Mary Morgan, London School of Economics; Laurence S. Moss, Babson College; Paul B. Trescott, Southern Illinois University; Jan van Daal, Erasmus University; Karen I. Vaughn, George Mason University; John K. Whitaker, University of Virginia.

Impending change of editor. Material for possible publication in JHET should be sent to Steven G. Medema, who will be the editor for issues appearing in 1999 and subsequently, at Journal of the History of Economic Thought, Department of Economics, University of Colorado at Denver, P. O. Box 173364, Denver, CO 80217-3364, USA. All papers that pass an initial screening are refereed. Papers must be submitted in triplicate, and must be double spaced, including footnotes and references. Books to be reviewed in JHET should also be sent to Steven G. Medema. The JHET style sheet and other information is available through http://www.iup.edu/ec/

Business correspondence, including orders and remittances relating to subscriptions, advertisements, back numbers and offprints, should be sent to the publisher: Carfax Publishing Ltd, PO Box 25, Abingdon, Oxfordshire OX14 3UE, UK.

The journal is published four times a year, in March, June, September, and December. These four issues constitute one volume. An annual index and title-page are bound in the December issue. 


\section{JOURNAL OF THE HISTORY OF ECONOMIC THOUGHT}

\section{SUBSCRIPTION RATES}

Foumal of the History of Economic Thought, Volume 20, 1998, 4 issues, ISSN 1042-7716

Institutional rate: $\_118.00$

North America US\$198.00

Personal rate: $\{48.00$

North America US\$68.00

Subscription rates include postage/air speeded delivery

\section{ORDERING INFORMATION}

Please complete in full the details on the Order Form and return to:

Carfax Publishing Ltd, PO Box 25, Abingdon, Oxfordshire OX14 3UE, UK

\section{OR TO}

Carfax Publishing Ldd, 875-81 Massachusetts Avenue, Cambridge, MA 02139, USA

OR TO

Carfax Publishing Ltd, PO Box 352, Cammeray, NSW 2062, Australia

By Fax:

$+44(0) 1235401550$ (UK)

+16173546875 (USA and Canada)

$+61(0) 299582376$ (Australia)

By Telephone:

+44(0)1235 401000 (worldwide, 24 hours, 7 days/week)

+18003541420 (USA and Canada)

+61(0)29958 5329 (Australia)

By Www:

http://www.carfax.co.uk

By E-mail:

sales@carfax.co.uk

For further details on the journal, including contents pages, please visit the Carfax Home Page at: http://www.carfax.co.uk/jht-ad.htm

Foumal of the History of Economic Thought (ISSN 1042-7716, UPS 016-592) is published quarterly. Periodicals Postage Paid at Rathway, N].

POSTMASTER: Send address changes to Carfax Publishing Limited, 875-81 Massachusetts Avenue, Cambridge, MA 02139, USA.

\section{COPYRIGHT}

No part of this publication may be reproduced, stored in a retrieval system or transmitted in any form or by any means, electronic, mechanical, photocopying, recording or otherwise without the written permission of the publisher.

(c) The History of Economics Society

Photocopying: For users in North America, permission is granted by the copyright owner for libraries and others registered with the Copyright Clearance Center (CCC) to make copies of any article herein for the flat fee of $\$ 7.00$ per article. Payment should be sent directly to CCC, 222 Rosewood Drive, Danvers, MA 01923, USA. The Item-fee Code for this publication indicates authorization to make copies only for internal or personal use. Serial-fee Code: ISSN 1042-7716, \$7.00. In the UK, the Copyright Licensing Agency (CLA), 90 Tottenham Court Road, London W $1 \mathrm{P}$ 9HE is mandated to grant permission to make copies.

ABSTRACTING AND INDEXING SERVICES foumal of the History of Economic Thought is indexed and abstracted in ABC-CLIO's America: History and Life

\section{ORDER FORM}

Please enter my subscription to fournal of the History of Economic Thought, Volume 20,1998, 4 issues, ISSN 1042-7716.

\section{Institutional rate}

$\square £ 118.00$

$\square$ North America US\$198.00

\section{Personal rate}

$\square £ 48.00$

North America US $\$ 68.00$

Personal subscriptions are welcomed if prepaid by credit card or personal cheque.

\section{METHODS OF PAYMENT}

Payment has been made to: Girobank plc, Bootle, Merseyside GIR OAA, UK Sort Code: 72-00-00. Account no: 04555821.

Payment has been made by bank transfer to: Bank of Scotland, Head Office, The Mound, Edinburgh EH1 1YZ, UK.

$\square$ f. Sterling Sort Code: 80-20-00. Account no: 00279048

Bank of Scotland International Division, PO Box 86, 120 St Vincent Street,

Glasgow G2 5DZ, UK

US\$ Sort Code: $80-20-13$ Account no: 25356USD01

Payment enclosed. Cheques or bank drafts should be made payable to Carfax Publishing Ltd and be drawn on a UK or US bank.

Please charge: $\square$ American Express $\square$ Eurocard

Number

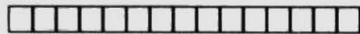

\section{Expiry Date}

Signature Date

Our Value Added Tax Registration number is

We are not registered for Value Added Tax

\section{INSPECTION COPY}

Please send me an inspection copy of fournal of the History of Economic Thought.

NAME

\section{ADDRESS}

\section{POST/ZIP CODE}

\section{COUNTRY}

TELEPHONE FAX

Carfax Publishing Ltd PO Box 25, Abingdon, Oxfordshire OX14 3UE, UK

875-81 Massachusetts Avenue, Cambridge, MA 02139, USA

PO Box 352, Cammeray, NSW 2062, Australia 


\section{Register to Receive \\ Contents Pages by E-mail}

\section{SARA - Scholarly Articles Research Alerting}

Carfax will e-mail to you the contents pages of any of our journals before we mail out the hard copy. This will give you advance warning of what is being published, enabling you to receive details of contents before the journals arrive in your library.

To register your interest, please either:

1 access the Carfax Home Page, enter SARA and follow the on-screen instructions; or

2 send an e-mail to SARA@carfax.co.uk with the word "info" in the body of the message; or

3 complete the Order Form and return to the address below. Remember to include your e-mail address and your full departmental postal address where available.

\section{ORDER FORM}

Please send a completed copy of this form to the address below.

Name

Department

Address

E-mail

Visit the Carfax Home Page at http://www.carfax.co.uk

Carfax Publishing Limited, PO Box 25, Abingdon, Oxfordshire OX143UE, UK 


\section{JOURNAL OF THE HISTORY OF ECONOMIC THOUGHT}

Volume 20

Number 3

September 1998

Articles

Samuel Hollander: The Canonical Classical Growth Model: Content, Adherence and Priority

Mark Tomass: On the Relativist Fallacy of the Impossibility of Value Neutral Inquiry in Political Economy

Claude Mouchot: A Comment on Philip Mirowski's Analysis of Utility Theory

John K. Whitaker: Rummaging in the Attic: A Chapter of Accidents

Masazumi Wakatabe: "The Creation of Wealth": John Rae's Knowledge-Based Growth Theory

J. Patrick Gunning: H. J. Davenport's Loan Fund Theory of Capital

Michael V. White: A Comment on Ekelund on Thornton

371

Robert B. Ekelund, Jr: Reply to White

\section{Book Reviews}

John B. Egger: The Austrian Theory of Value and Capital: Studies in the Life and Work of Eugen von Böhm-Bawerk, by Klaus H. Hennings

Salim Rashid: On the Origins of Classical Economics, by Tony Aspromourgos

Warren J. Samuels: The Makers of Modern Economics, vol. 3, edited by Arnold Heertje

Notices and Communications 


\title{
HISTORY OF ECONOMICS SOCIETY
}

\author{
Founded in 1974 \\ Officers 1998-1999
}

President: David C. Colander, Middlebury College. President-Elect: Bruce J. Caldwell, University of North Carolina at Greenboro. Vice President: Betsy Jane Clary, College of Charleston. Secretary-Treasurer: John J. Bethune, University of Tennessee-Martin. The Executive Committee consists of the foregoing and the following officers. Past Presidents: Malcolm Rutherford, University of Victoria; Robert W. Clower, University of South Carolina. Elected Members: Philip Mirowski, University of Notre Dame (1999); Mary Morgan, London School of Economics (1999); Jerry Evensky, Syracuse University (2000); Judy Klein, Mary Baldwin College (2000). Editor of JHET: Donald A. Walker, Indiana University of Pennsylvania. Manager of Electronic Information: Ross B. Emmett, Augustana University College.

The web page address for the HES is http://cs.muohio.edu/ HisEcSoc/

An annual individual subscription which also provides one year's membership in the History of Economics Society is $\$ 30$. This must be paid in US funds drawn on a US bank. Requests for individual-member subscriptions, and notices of a change of address for such subscriptions should be sent to John J. Bethune, HES Secretary-Treasurer, Department of Economics, University of Tennessee-Martin, Martin, TN 38238, USA.

Subscriptions for institutions and for individuals who do not wish to become HES members can be obtained from Carfax Publishing Ltd. With immediate effect, all orders and remittances relating to orders and renewals for those classes of subscriptions for 1998 should be addressed to:

\author{
Carfax Publishing Ltd \\ PO Box 25 \\ Abingdon, Oxfordshire \\ OX14 3UE \\ UK \\ Tel.: $+44(0) 1235401000$ \\ Fax: + $44(0) 1235401550$ \\ E-mail: enquiries@carfax.co.uk \\ or to: \\ Carfax Publishing Ltd \\ 875-81 Massachusetts Avenue \\ Cambridge, MA 02139 \\ USA \\ Tel: +18003541420 \\ Fax: + 16173546875 \\ or to: \\ Carfax Publishing Ltd \\ PO Box 352 \\ Cammeray, NSW 2062 \\ Australia \\ Tel.: + $61(0) 299585329$ \\ Fax: + $61(0) 299582376$ \\ E-mail: carfax@ibm.net
}

Effective immediately, all enquiries and orders for back issues will be dealt with by Carfax Publishing Ltd at the above addresses. Requests for permission to reprint material appearing in JHET should be addressed to Carfax at the Abingdon address. 